\title{
シリルエノールエーテルおよびシクロプロ ピルシリルエーテルと遷移金属塩の反応
}

\section{伊 藤 嘉 彦* 三 枝 武 夫*}

\author{
Reactions of Silyl Enol Ethers and Silyl Cyclopropyl \\ Ethers with Transition Metal Salts.
}

Yoshihiko Ito and Takeo SAEgusA*

\begin{abstract}
This paper describes a series of reactions of silyl ethers of enols and cyclopropanols with metal salts, in which metal enolates and metal cyclopropoxides may be assumed as key intermediates : (i) Silyl enol ethers are reacted with $\mathrm{Ag}_{2} \mathrm{O}$ in DMSO to give 1,4-diketones. (ii) Silyl enol ethers are reacted with $\mathrm{CuCl}_{2}$ in $\mathrm{DMF}$ and $\mathrm{FeCl}_{3}$ in acetonitrile to give $\alpha$-chloroketones. (iii) Silyl cyclopropyl ethers are reacted with $\mathrm{FeCl}_{3}$ in $\mathrm{DMF}$ to afford $\beta$-chloroketones which are derived from ring-opening. Especially, in the reaction of 1-trimethylsilyloxybicyclo [n. 1.0] alkanes with $\mathrm{FeCl}_{3}$, the bridging bond is regioselectively cleaved to produce $\beta$-chlorocycloalkanones. (iv) Silyl enol ethers of pinacolone and camphor are reacted with $\mathrm{PdCl}_{2}\left(\mathrm{PhCN}_{2}\right.$ to afford air-stable $\mathrm{Pd}$ (II) complexes, which react with ethylene and butadiene by an addition-elimination mechanism to lead carbon-carbon bond formation at the $\alpha$-carbon of ketone. $\mathrm{PdCl}_{2}\left(\mathrm{PhCN}_{2}\right.$ promotes intramolecular cyclization of 2-trimethylsilyloxy-5-substituted-1,5-hexadienes to give $\sigma$-(1-substituted-3oxocyclopentyl) methylpalladium (II) complexes, which can be reacted with a variety of olefins to afford 3,3-disubstituted cyclopentanones.
\end{abstract}

エノール化可能なアルデヒドやケトンを塩基の存在下, クロロトリメチルシランと反応させて容易に得られるシ リルエノールエーテルは求核的なオレフィンであり，そ の強い求核性を利用した合成反応は数多く知られている。 向山らの見出した $\mathrm{TiCl}_{4}$ 触媒を用いるシリルエノールエ ーテルとカルボニル化合物の反応によるクロスアルドー ル合成 ${ }^{1)} ル イ ス$ 酸触媒によるシリルエノールエーテル と第三級アルキルクロリドの反応 ${ }^{2}$ などもこの種の反応 と考えられる。<smiles></smiles><smiles>[R]C(=O)OCCCC</smiles>
$\mathrm{O}$<smiles>[R]/C(=C\C)O[As](C)(C)C</smiles>
$+\quad \mathrm{R}^{2} \mathrm{R}^{3} \mathrm{R}^{4} \mathrm{CCl}$

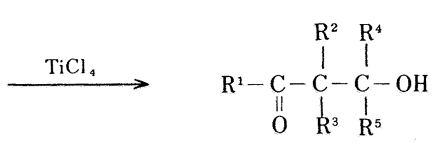

一方, シリルエノールエーテルのシリコンー酸素結合は 有機リチウムにより容易に切断され，リチウムエノレー トを与える。リチウムエノレートの合成反応での有用性 はいうまでもない3)。著者らはシリルエノールエーテル のシリコンー酸素結合が容易に切断されることに着目し， リチウム以外の金属化合物によってシリコン一酸素結合 を切断し，金属エノレード中間体を生成させることがで きれば，金属の性質に応じて，金属エノレートは種々の 反応性を示すと考えた。

* Department of Synthetic Chemistry, Faculty of Engineering

() 


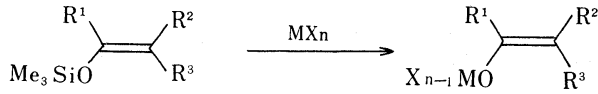

この総説で述ベるシリルエノールエーテルと金属塩の反 応はこの考えに基づいて主として著者らによって見出さ れたものである。さらに, この考えはシクロプロピルシ リルエーテルにも展開することができ，環状ヶトンの環 拡大反応など新しい合成反応を見出している。

1. シリルエノールエーテルの遷移金属による酸化 的二量化反応一1, 4-ジケトンの新合成法

シリルエノールエーテルを DMSO, DMF および $\mathrm{H}-$ MPA など非プロトン性極性溶媒中, $\mathrm{Ag}_{2} \mathrm{O}$ と加熱する と次式に従って，良好な収率で 1,4-ジケトンが得られ る。

$$
\begin{aligned}
& \stackrel{\mathrm{R}^{1} \mathrm{C}}{\mathrm{C}}=\mathrm{CHR}^{2} \quad \stackrel{\mathrm{Ag}_{2} \mathrm{O}}{\mathrm{DMSO}}
\end{aligned}
$$

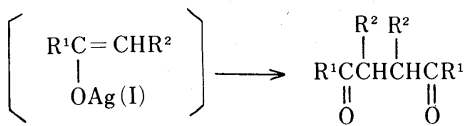

この反応ではケトンの酸化的二量化を位置選択的に行わ せることができる点で, 合成反応として興味深い4）。著 者らは，この反応を銀（I）エノレート中間体を仮定し， その分解によって生成すると思われるビニルオキシラジ カルの再結合によって説明している。この種の反応機構 はフェノール類の遷移金属塩による酸化的二量化および 重合反応で知られているう。

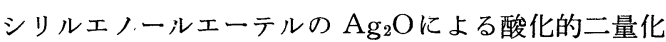
反応ではカップリング位置でのアルキル置換基（式 (4) $\mathrm{R}^{2}$ 基) は生成物 1,4-ジケトンの収率を低下させる。こ れに対し，ケトンのラジカル的な二量化反応では，1,4ジケトンの混合物を与えるが，この場合には，主生成物 は多置換 $\alpha$-炭素でのカップリングによるものである ${ }^{6)}$ 。

適当な反応条件を選ぶことにより二種類のシリルエノ ールエーテルを $\mathrm{Ag}_{2} \mathrm{O}$ にって交互二量化させることもで きる。有機合成として興味があるのは，アセトンのよ5 な一種類のエノール化水素をもつメチルケトンのエノー ルシリルエーテルを一成分とする酸化的交互二量化反応 である。たとえば,
3<smiles>C=CO[Sb](C)(=O)=O</smiles>

$$
\mathrm{C}_{6} \mathrm{H}_{11} \mathrm{C}=\mathrm{CH}_{2}
$$

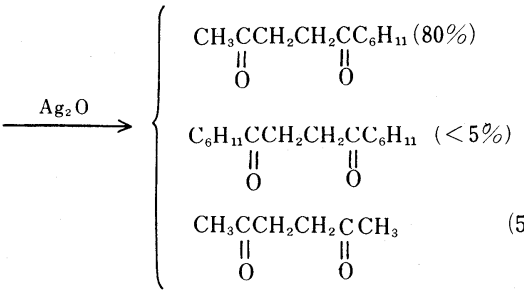

ここで得られる 2,5 -ウンデカンジオンはジヒドロジャ スモン合成の中間体である。

シリルエノールエーテルの酸化的カップリングは $\mathrm{Cu}_{2} \mathrm{O}$ 存在下 $\mathrm{Cu}(\mathrm{II})(\mathrm{OTf})_{2}$ によっても同様に起こることが 小林, 田口らによって報告されている7)。(Tf は $\mathrm{CF}_{3}$ $\mathrm{SO}_{2}$, Triflate の略)。また, 尾島らによって見出された エステルェノールシリルェーテルと $\mathrm{TiCl}_{4}$ の反応による コハク酸誘導体の合成も, この種の反応と見られる ${ }^{8)}$ 。
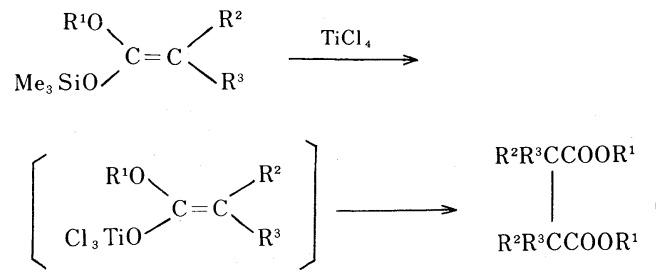

2. シリルエノールエーテルと $\mathrm{CuCl}_{2}$ および $\mathrm{FeCl}_{3}$ による $\alpha$ クロルケトンの合成

シリルエノールエーテルを $\mathrm{DMF}$ 溶媒中, $2 \sim 3$ モル 当量の $\mathrm{CuCl}_{2}$ と反応させると $\alpha$-クロルケトンが良好な 収率で得られる ${ }^{9)}$ 。

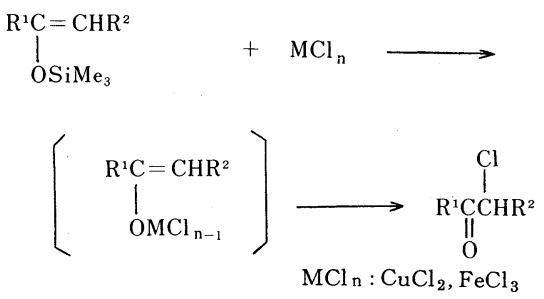

この反応は不対称ケトンを位置選択的に $\alpha$-クロル化す る方法として簡便である。ケトンを $\mathrm{CuCl}_{2}$ で直接クロル 化する方法が知られているが10), 不対称ケトンでは $\alpha$ クロルケトンと $\alpha^{\prime}$ クロルケトンの混合物を与えるもの であり，従来法は有機合成反応としての利用に制限があ る。 $\mathrm{FeCl}_{3}$ もまたシリルエノールエーテルと反応し, $\alpha-$ クロルケトンを与える。この場合, アセトニトリル溶媒 の使用が良好な結果を与える。 $\mathrm{CuCl}_{2}$ と $\mathrm{FeCl}_{3}$ の反応性 の顕著な差異が次に示すような分子内にオレフィンをも つシリルエノールエーテとの反応で見られる。 $\mathrm{CuCl}_{2}$ と 
の反応では $\alpha$ クロルケトン 1 を与えるだけであるが, $\mathrm{FeCl}_{3}$ との反応では $\alpha$-クロルケトン 1 の他に環状ク口 ルケトン 2 および二量化生成物 1, 4-ジケトン 3 が得られ る。

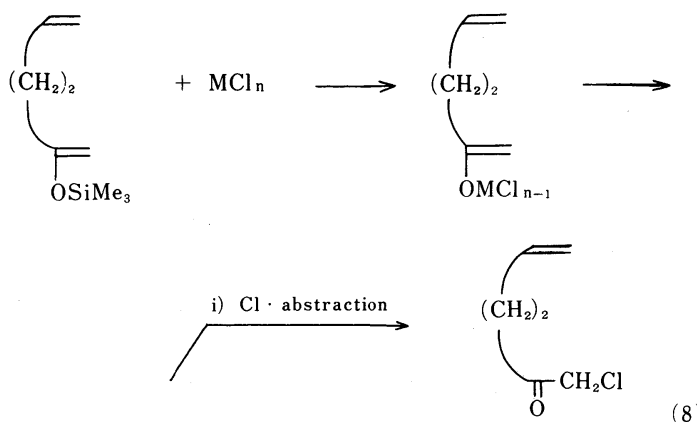

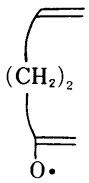
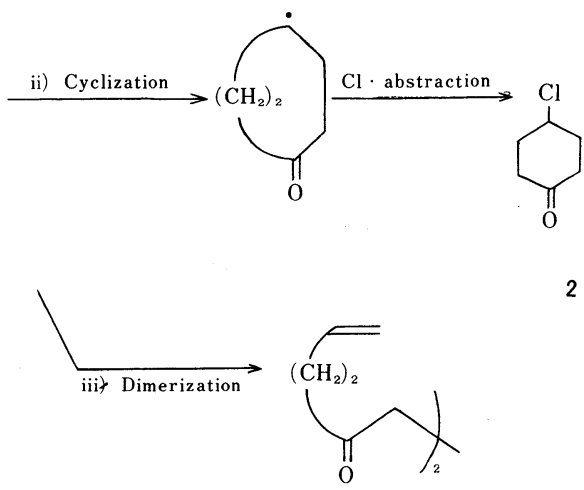

この事実はシリルエノールエーテルと $\mathrm{FeCl}_{3}$ との反応が ビニルオキシラジカルを中間体とするものであることを 示している。すなわち，ビニルオキシラジカルが競争的 に i） $\mathrm{FeCl}_{3}$ よりクロルラジカルの引き抜き ii） 分 子内オレフィンへの付加により環化し，つづいてクロル ラジカルの引き抜き iii) ラジカルの再結合による二量 化一寸ることにより各生成物を与えると考えられる。こ こで, $\mathrm{CuCl}_{2}$ と $\mathrm{FeCl}_{3}$ の反応性の差異については十分明 らかでないが，金属の redox potentialの差が一つの説 明であろう。

\section{3. シクロプロピルシリルエーテルの遷移金属塩に}

\section{よる酸化的環開裂反応}

シクロプロピルシリルエーテルを室温 $\mathrm{DMF}$ 中, $\mathrm{FeCl}_{3}$ や $\mathrm{CuCl}_{2}$ と反応させると容易に環開裂し, $\beta$-クロルケ トンおよび $\alpha, \beta$-不飽和ケトンが生成する。合成反応と して，興味樑いのは，1-シリルオキシビシクロ [n. 1.0] アルカンと $\mathrm{FeCl}_{3}$ の反応で, 選択的に架橋結合が切断
して，高収率で，環状 $\beta$-クロルケトンを与えることで ある(式 (9) $)^{10) 。}$

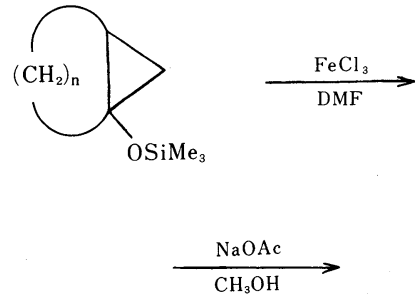<smiles>O=C1CCCCC(Cl)C1</smiles>

環状 $\beta$-クロルケトンは容易に環状 $\alpha, \beta$-不飽和ケトンに 導くことができる。

1-トリメチルシリルオキシビシクロ [n.1.0]アルカン は各種環状ヶトンのエノールシリルエーテルに. Simmons-Smith 反応して得られるから，この反応は環状ヶ トンを炭素ユニット 1 箇だけ環拡大する新しい手法であ る。不対称環状ケトンでは位置選択的に炭素 1 箇だけ環 拡大寸ることができるので, 合成反応としての有用性は 高(11)。この環拡大反応は次のよ5に, 1-シリルオキシ ビシクロ [n.1.0.] アルカンのシリコン一酸素結合が $\mathrm{FeCl}_{3}$ によって切断されて, 鉄（III）アルコキシド中間 体が生成し, その分解によりアルコキシラジカルが発生 するとして説明されている。
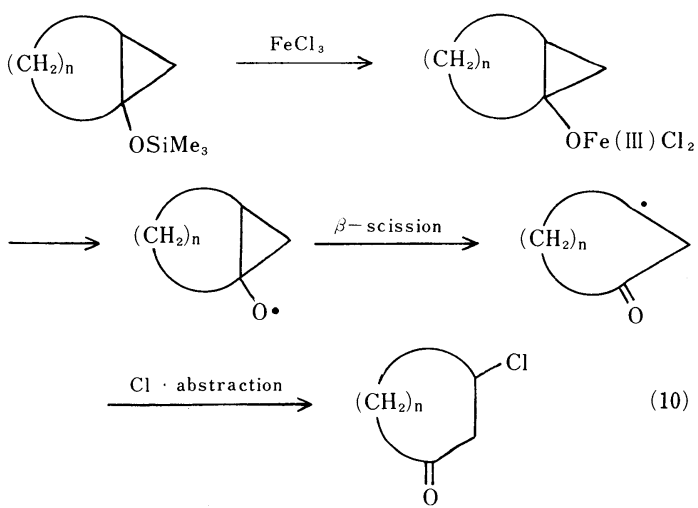

反応機構は異なるが，類似の環状ケトンのエノールシリ ルエーテルの環拡大反応が知られている ${ }^{12,13) 。 ~}$
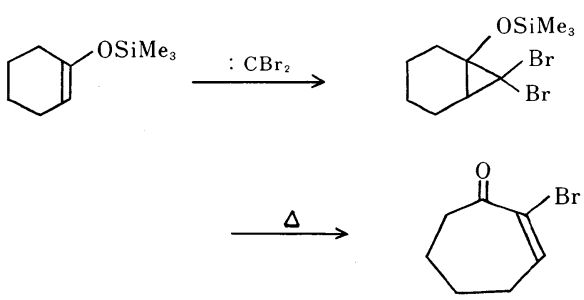


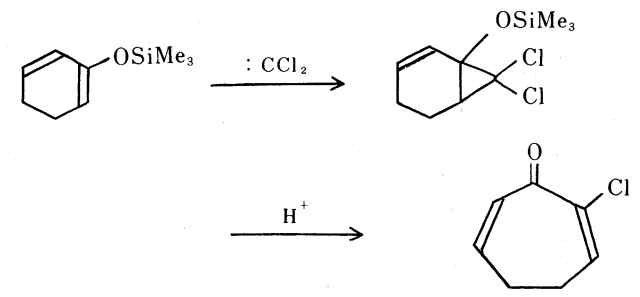

Stork らは，この反応を利用してシクロドデカノンから 次のスキームに従って $d l$ ムスコンを合成している ${ }^{14)}$ 。
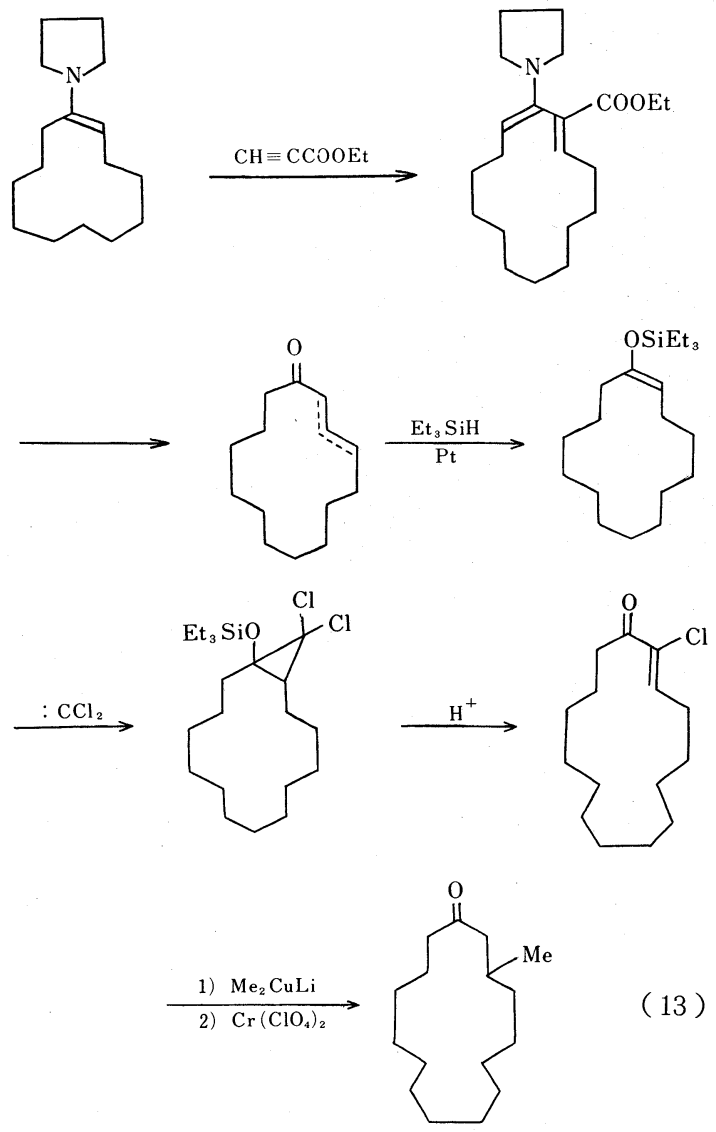

1-シリルオキシビシクロ [n.1.0]アルカンの $\mathrm{FeCl}_{3}$ に よる環開裂反応はさらにビスートリメチルシリルオキシ ビシクロ [n.1.0]アルカンにも展開することができて, 環状 1,3-ジヶトンが得られる。7〜15員環 1,3-ジケトン が好収率で合成される ${ }^{11)}$
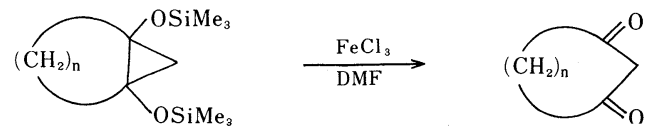

(14)
出発原料のビスートリメチルシリルオキシビシクロ [n. 1.0.] アルカンはジカルボン酸ジェステルをトリメチルシリル クロリドの存在下, 分子内アシロイン縮合させ, 得られ る環状エンジオールトリメチルシリルエーテルをジェチ ル亜鉛・ジョードメタンでシクロプロパン化することに より合成できるので，この反応は環状 $1,3-$ ジヶトンの一 般的な合成法として有用である。

この方法で合成される 15 員環 1,3-ジケトンから次の ように $d, l$ ムスコンが合成される ${ }^{15)}$ 。
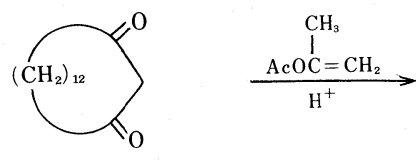<smiles>CC(=O)OC1=CC(=O)CCCC1</smiles>

$$
\text { 1) } \underset{\mathrm{Me}_{2} \mathrm{CuLi}}{\text { 2) } \mathrm{H}_{2} / \mathrm{Pd}} \longrightarrow
$$<smiles>CCCCCCCCCCCCCCCC(C)(C)CC</smiles>

長鎖ジカルボン酸ジェステル $\mathrm{RO}_{2} \mathrm{C}\left(\mathrm{CH}_{2}\right)_{\mathrm{n}} \mathrm{CO}_{2} \mathrm{R}(\mathrm{n}$ =7〜 12)をトリメチルシリルクロリド存在下，アシロイ ン縮合させると分子内アシロイン縮合と競争的に二分子 間でアシロイン縮合して環状のアシロイン二量体が相当 量得られる ${ }^{16)}$ 。

$$
\mathrm{RO}_{2} \mathrm{C}\left(\mathrm{CH}_{2}\right)_{\mathrm{n}} \mathrm{CO}_{2} \mathrm{R} \underset{\mathrm{Me}_{3} \mathrm{SiCl}}{\longrightarrow}
$$

この環状アシロイン二量体をシクロプロパン化し, ひき つづき, $\mathrm{FeCl}_{3}$ で処理することにより大環状ビスー1,3ジケトンが合成される ${ }^{17)}$ 。
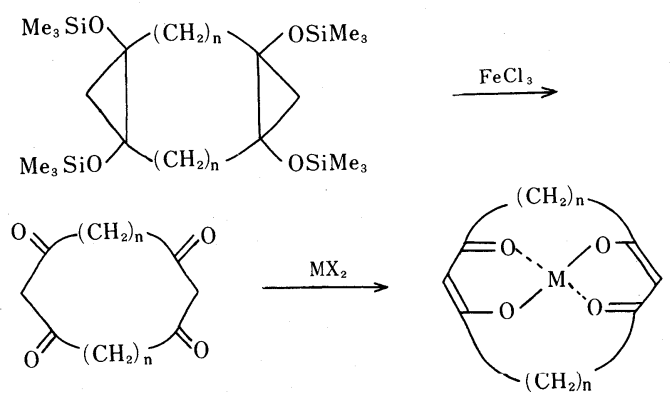

$\mathrm{n}=7,8,10,12$ 
こらして得られる20，22，26および30員環状ビス-1,3ジケトンはケトーエノール互変異性体混合物で, その異 性体比はアセチルアセトンのそれとほぼ同程度であり, $\mathrm{Cu}^{2+}, \mathrm{Ni}^{2+}, \mathrm{Co}^{2+}$ など遷移金属イオンと容易に $1 ： 1$ 錯 体を形成する ${ }^{17}$ 。

大環状ビス-1,3-ジヶトンはその活性メチレン基を利 用してクロルメチル化ポリスチレンに固定することがで きる。これは有害重金属の捕集や有用金属の回收への用 途が期待される ${ }^{17}$ 。<smiles>CC(C)(C)c1ccc(C(C)(C)C)cc1</smiles><smiles>O=C1CCC(=O)CCC(=O)CC(=O)CC1</smiles><smiles>CC(C)C(C)(C)c1ccc(CC2C(=O)CCC(=O)CC(=O)CCC(=O)C2Cc2ccccc2)cc1</smiles>

シクロプロピルシリルエーテルの金属塩による環開裂 反応として, 最近, 村井, 園田らは $\mathrm{AgBF}_{4}$ および $\mathrm{Cu}-$ $\left(\mathrm{BF}_{4}\right)_{2}$ との反応で 1, 6-ジケトンの生成を報告している 19)。この場合には, シクロプロパン環の開裂の方向が著 者らの反応と異っている点が注目される。<smiles>CC12CCCCC1C2</smiles>
$\mathrm{OSiMe}_{3}$

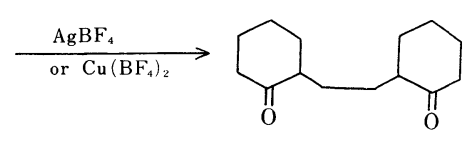

また, Rubottom らはシクロプロピルシリルエーテルと $\mathrm{Pd}(\mathrm{OAc})_{4}$ との反応で，上記のものと異った環開裂の型 式を報告している ${ }^{20)}$ 。

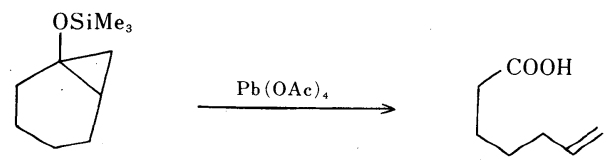

\section{4、 $\mathrm{Pd}(\mathrm{II})$ 塩によるシリルエノールエーテルの新反応}

4.1. シリルエノールエーテルと $\mathrm{Pb}(\mathrm{II}) \mathrm{Cl}_{2}(\mathrm{PhCN})_{2}$ の反応 オキサー $\pi-$ アリルパラジウム錯体の化学は $\pi-$
アリルパラジウム錯体の化学との比較の上で興味深いが, 一般的なオキサく, 今までには, 反応中間体として想定されていること はあってもその化学は明らかでない。すでに述べてきた ように, シリルエノールエーテルと種々の金属塩との反 応では, 金属エノレート中間体の生成が考えられる。筆 者らは, この知見に基づいて, シリルエノールェーテル と $\mathrm{Pd}(\mathrm{II})$ 塩との反応がオキサー 体への一つのアプローチとなると考えた。

実際, ピナコロン, アセトフェノンなどメチルケトン のエノールシリルエーテルは $\mathrm{Pd}(\mathrm{II}) \mathrm{Cl}_{2}(\mathrm{PhCN})_{2}$ と速 やかに反応して, 次式に示寸組成のパラジウム (II)錯体 を高収率で与える。赤外スペクトルは $1,507 \mathrm{~cm}^{-1}$ に強い 吸収を示す。

$$
\begin{aligned}
& \stackrel{\mathrm{RC}=\mathrm{CH}_{2}}{{ }_{\mathrm{OSiMe}}}+\mathrm{Pd}(\mathrm{II}) \mathrm{Cl}_{2}(\mathrm{PhCN})_{2} \longrightarrow
\end{aligned}
$$

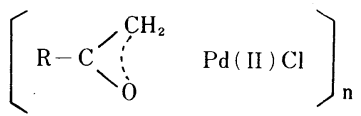

カンファーのエノールシリルエーテルも同様なパラジウ 么錯体を与えるが，赤外スペクトルは $1,630 \sim 1,660 \mathrm{~cm}$ ${ }^{-1}$ に強い吸収を示す。これらの錯体はいずれも会合度が 高く, 黄色粉末で, 結晶化しないため, 正確な構造は明 らかでない21)。

$t$-ブチルネオペンチルケトンのエノールシリルエーテ ルと $\mathrm{Pd}(\mathrm{II}) \mathrm{Cl}_{2}(\mathrm{PhCN})_{2}$ の反応も同様に起こる。元素 分析, 分子量測定, 赤外スペクトル $\left(1,650 \mathrm{~cm}^{-1}\right)$ 扰よ び核磁気スペクトル $(\delta 4.00(\mathrm{~S}, 1 \mathrm{H}))$ から次の三核パ ラジウム錯体でパラジウムエノレート構造か, アシルメ チルパラジウム構造のいずれかと思われるが，決定でき ない。

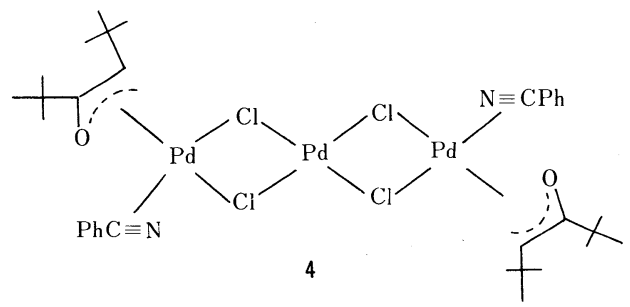

ネオペンチルフェニルケトンのエノールシリルエーテル と $\mathrm{Pd}(\mathrm{II}) \mathrm{Cl}_{2}(\mathrm{PhCN})_{2}$ の反応も同じ種類のパラジウム 錯体を与える。

以上述べたパラジウム錯体はいずれも一酸化炭素, エ チレン, ブタジェンと反応し，ヶトンの $\alpha$ - 炭素とパラ ジウムの間に挿入する ${ }^{21)}$ 。 
$4 \underset{\text { 1) } 50 \mathrm{~atm} . \mathrm{CO}}{\stackrel{\text { 2) } \mathrm{C}_{2} \mathrm{H}_{5} \mathrm{OH}}{\longrightarrow}}$<smiles>CCOC(=O)C(C(=O)C(C)(C)C)C(C)(C)C</smiles>

4

1) 50 atm. $\mathrm{CH}_{2}=\mathrm{CH}_{2}$<smiles>C=CC(C(=O)C(C)(C)C)C(C)(C)C</smiles>

(>95\%)

(24)

$86 \%$
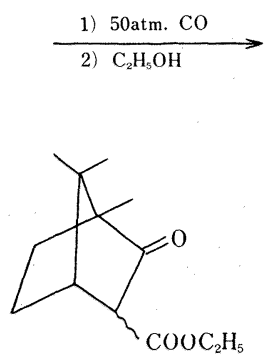

$[85 \%(e x o: e n d o=1: 4)\rfloor$

エーテルと $\mathrm{Pd}(\mathrm{II})(\mathrm{OAc})_{2}$ が反応して,有機パラジウム (II) 中間体 5 を形成し，ひきつづいて，パラジウム一炭 素結合間に分子内オレフィンが挿入し，環化するが，こ

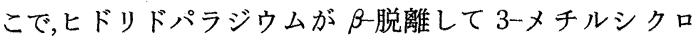
ペンテノン誘導体 9 になると理解できる。<smiles>[R]C(=C)C([R])C([R])C(=C)O[Na]</smiles><smiles>C1CC2C3CC2C13</smiles><smiles>[R]C(=C)C([R])C([R1])C(C)=[18O]</smiles><smiles>[R10]CC1([R])CC(=O)C([R])C1[R]</smiles>

4. 2. $\mathrm{Pd}(\mathrm{II})$ 塩によるシリルエノールエーテルの環化 反応 4.1.で述べたようにシリルエノールエーテルは $\mathrm{Pd}$ (II)塩と反応して有機パラジウム (II) 錯体を与え, それはオレフィンと挿入反応して炭素一炭素結合形成が 行われる。従って, 分子内にオレフィン結合をもつシリ ルエーテルと Pd(II) 塩との反応では, 環化反応を行わ せることができる。2-トリメチルシリルオキシー1, 5-ヘ キサジェンや 1-(1-トリメチルシリルオキシビニル)-2ビニルシクロヘキサンはアセトニトリル中, 一当量の $\mathrm{Pd}(\mathrm{II})(\mathrm{OAc})_{2}$ と反応してほぼ定量的に 2-メチルシク口 ペンテノン誘導体になる ${ }^{22)}$ 。<smiles>C=CCCC(=C)OC</smiles><smiles>CC1=CC(=O)CC1</smiles><smiles>C=CC1CCCCC1C(=C)O[Na]</smiles><smiles>CC1=CC(=O)C2CCCCC12</smiles>

2-トリメチルシリルオキシ-1, 6-ヘプタジエンも $\mathrm{Pd}(\mathrm{II})-$ $(\mathrm{OAc})_{2}$ によって環化するが，生成物 3-メチルシクロへ キセノンの收率は低い。

この反応は次のスキームに示すようにシリルエノール

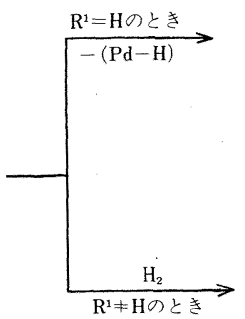<smiles>[R]C1C(=C)CC(=O)C1[R2]</smiles><smiles>[R]C1C(=O)C=C(C)C1[R]</smiles><smiles>[R]C1C(=O)CC([R])(C)C1[R]</smiles>

10

(28)

上のスキームで $\mathrm{R}^{1} \neq \mathrm{H}$ のときパラジウム (II) 錯体 7 は ヒドリドパラジゥムの $\beta$ 脱離の可能性はなく安定に単離 できる。たとえば，2-トリメチルシリルオキシー5-メチ ル-1,5-ヘキサジェンをベンゼン中，一当量の Pd(II)$\mathrm{Cl}_{2}(\mathrm{PhCN})_{2}$ と反応すると, ほぼ定量的に安定な有機パ ラジウム (II) 錯体 6 となる。これをアセトニトリル中, 加熱すると環化してパラジウム (II) 錯体 7 をえる。パ ラジウム錯体 7 を水素ガスと接触させると定量的に $3,3-$ ジメチルシクロペンタノンが得られる ${ }^{23)}$ 。

次のシリルエノールエーテル 11 む同様に環化し, 水 素分解すると1-メチルビシクロ [n.3.0]アルカノンを好 收率で与える。ここで，注目されるのは $\mathrm{n}=3$ および 4 では生成するビシクロ環の ring junctionの立体化学は 選択的にシスであるのに対し， n=5 では ring junction の立体化学はトランス $(>90 \%)$ である。 


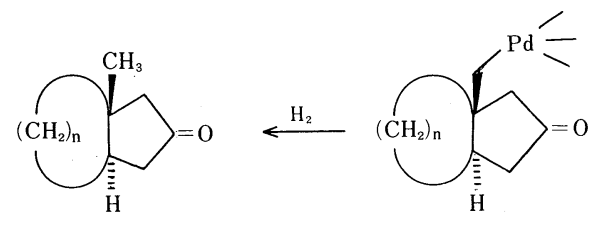

$\mathrm{Pd}(\mathrm{II}) \mathrm{Cl}_{2}(\mathrm{PhCN})_{2}$

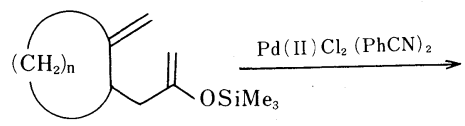

$\mathrm{n}=5$

11

$\mathrm{n}=3,4$

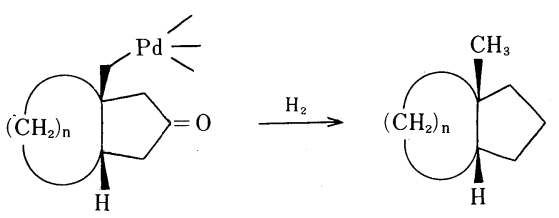

(29)

2-トリメチルシリルオキシー5-置換-1, 5-ヘキサジェン の $\mathrm{Pd}(\mathrm{II}) \mathrm{Cl}_{2}(\mathrm{PhCN})_{2}$ による環化反応で生成する安定 な有機パラジウム（II）錯体7はさらにオレフィンや一酸 化炭素と反応して炭素一炭素結合形成することができる ${ }^{23}$ 。

$$
7+\mathrm{CH}_{2}=\mathrm{CHR} \longrightarrow \mathrm{n}_{\mathrm{O}}^{\mathrm{R}^{2}}
$$<smiles>[R]C1C(=O)CC([R1])(CC(=O)OCC)C1[R]</smiles>

合成反応として興味樑い例を以下に示す。
4. 3. $\mathrm{CuCl}_{2}$ によるパラジウム一炭素結合の酸化反応 パラジウム一炭素結合を $\mathrm{CuCl}_{2}$ で酸化的に切断する 試みはいくつか知られている。Bäckvall はエチレンを aminopalladation し, それを求核剤の存在下に酸化して, アミノアルコールやジアミンを立体特異的に合成してい $3^{24)}$ 。

筆者らは4.2. で述べた $\sigma$-(1-置換-3-オキソシクロペ ンチル) メチルパラジウム (II) 錯体7のパラジウム一炭 素結合を $\mathrm{CuCl}_{2}$ で酸化すると次式に示すように炭素骨 格転位が起こって環拡大寸ることを見出した ${ }^{25) 。 ~}$

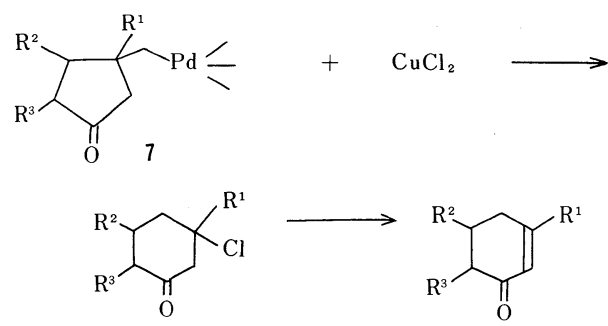

特に，興味深いのは $\sigma-1$-(ビシクロ [n. 3.0]アルカノン) メチルパラジウム (II) 錯体 12 の $\mathrm{CuCl}_{2}$ による酸化的 転位反応である。 $\sigma-1$ - ( cis-fused ビシクロ [3.3.0] オク タノンー3) メチルパラジウム (II) 錯体拉よび $\sigma-1-(c i s-$ fused ビシクロ [4.3.0]ノナノン-8）メチルパラジウム (II) 錯体では架橋結合が選択的に転位して環拡大する (式 (36))。

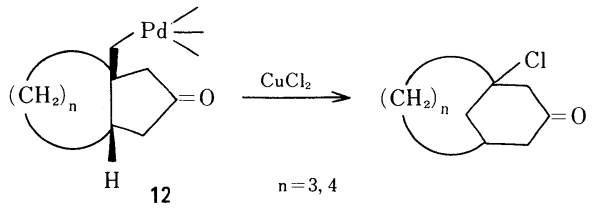<smiles>CC1(C[14C](C)(C)C)CCC(=O)C1</smiles><smiles>C=CC(C)=O</smiles><smiles>CCCCCCC</smiles><smiles>CC(=O)/C=C/C=C/CSC1(C)CCC(=O)C1</smiles><smiles>CC1=C2C(=O)CCC2(C)CCC1</smiles><smiles>CC(C)(C)N=CC1CC(=O)C[C@H]2CCC[C@H]12</smiles><smiles>C=CC(C)=O</smiles><smiles>C1CC1</smiles><smiles>CC(=O)/C=C\C12CCC[C@H]1CC(=O)C2</smiles><smiles>CC1CCC1C</smiles><smiles>CC1=C2[CH][C@@]3(CCC1)CCC[C@@H]3CC2=O</smiles><smiles>C1CC1[13CH]1CC1</smiles><smiles>O=C1C[C@H]2CCCC[C@]23CCC=CC13</smiles><smiles>C[PH2+]C[C@]12CCCCC[C@H]1CC(=O)C2</smiles>

$+\quad \mathrm{CH}_{2}=\mathrm{CHCHO}$<smiles>CC</smiles><smiles>O=C/C=C/C[C@@]12CCCCC[C@H]1CC(=O)C2</smiles>
1) $\mathrm{H}_{2} / \mathrm{Pd}$ H 
これに対して $\sigma-1$-(trans-fused ビシクロ [5.3.0] デカ ンノン-9-)メチルパラジウム (II) 錯体ではトリシクロ $[5$. 3.1.0]ウンデカノンが生成する（式 (37))。<smiles>C=C(C)CC12CCCCC[C@H]1CC(=O)C2</smiles>

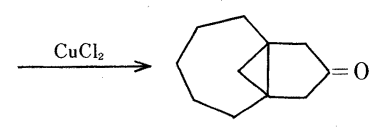

これらの反応機構の詳細は明らかでない。

4. 4. Pd(II)によるシリルエノールエーテルの脱ヒド ロシリレーションー $\alpha, \beta$-不飽和ヶトンの合成 シリ ルエノールェーテルはアセトニトリル中, 一当量の $\mathrm{Pd}-$ (II) $(\mathrm{OAc})_{2}$ と速やかに反応して, 脱七ドロシリル化し, 高収率で， $\alpha, \beta$-不飽和カルボニル化合物を生成する ${ }^{26)}$ 。

$$
\begin{aligned}
& \begin{array}{l}
\mathrm{R}{ }^{1} \mathrm{C} \\
\quad=\mathrm{CHCH}_{2} \mathrm{R}^{2}
\end{array} \underset{\mathrm{OSiMe}}{ }+\mathrm{Pd}(\mathrm{II})(\mathrm{OAc})_{2} \longrightarrow
\end{aligned}
$$

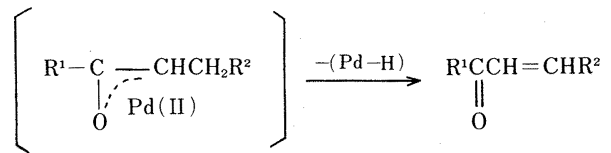

この反応は 4.1. で述べたよ5に, シリルェノールェー テルと Pd(II) 塩の反応で有機パラジウム (II) 錯体が一 たん生成し次にヒドリドパラジウムが $\beta$-脱離したもの である。反応の進行につれてパラジウム金属が析出する。 従って, パラジウム $(\mathrm{O})$ を再酸化して $\mathrm{Pd}(\mathrm{II})$ にするこ とによりこの反応を触媒的にすることができる。 $\mathrm{Pd}(\mathrm{II})-$ $(\mathrm{OAc})_{2}+\mathrm{Cu}(\mathrm{II})(\mathrm{OAc})_{2}+\mathrm{O}_{2}$ 系によってシリルエノー ルエーテルの脱ヒドロシリル化が触媒的に行われる。

この方法により不対称ケトンはそれぞれのエノールシ リルエーテルを経て, 位置選択的に $\alpha, \beta$-不飽和ケトン にすることができる。また， $\alpha, \beta$ 不飽和ケトンに $\mathrm{R}_{2} \mathrm{Cu}-$ $\mathrm{Li}$ 共役付加させ, 生じるエノレートをトリメチルシリ ルクロリドと反応させてシリルエノールエーテルを合成 し，これを $\mathrm{Pd}(\mathrm{II})(\mathrm{OAc})_{2}$ で脱ヒドロシリル化して $\beta$ 置換- $\alpha, \beta$-不飽和ケトンを得ることができる（式(39))。

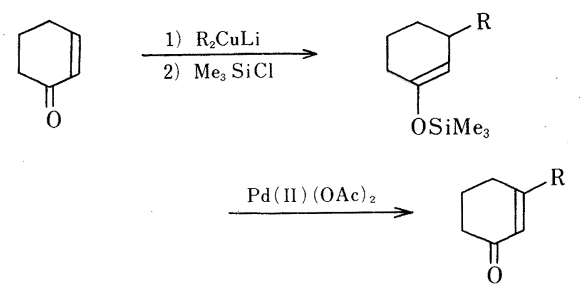

アルデヒドのエノールシリルエーテルも $\mathrm{Pd}(\mathrm{II})(\mathrm{OAc})_{2}$ と同様に反応して高収率で $\alpha, \beta$-不飽和アルデヒドを与
える。

$$
\begin{gathered}
\stackrel{\mathrm{CH}=}{\mathrm{C}}=\mathrm{CHCH}_{2} \mathrm{R} \\
\mathrm{Me}_{3} \mathrm{SiO} \\
\longrightarrow \mathrm{PCH}=\mathrm{CHCHO}
\end{gathered}
$$

しかし, カルボン酸エステルのエノールシリルエーテル の脱ヒドロシリル化反応による $\alpha, \beta$-不飽和エステルの 合成は幾分収率が低い。

以上でシリルェノールェーテルおよびシクロプロピル シリルエーテルと金属塩の反応についての紹介を終える が，ここで用いられている金属はいずれも共通して酸化 能のあるものである。このことがシリルエノールエーテ ルのシリコン一酸素結合の切断の機構と関係していると 筆者は考えている。この点を考慮して探索すれば，まだ まだ，新反応開拓の余地は残されているであろう。この 小文が合成研究の一助になれば望外の幸である。

（昭和 54 年 12 月 21 日受理）

$$
\text { 文献 }
$$

1a) T. Mukaiyama, K. Narasaka, K. Banno, Chem. Lett., 1973, 1011

b) T. Mukaiyama, K. Banno, K. Narasaka, J. Am. Chem. Soc., 96, 7503 (1974)

2) M.T. Reetz, W.F. Maier, Angew. Chem., Int. Ed. Engl., 17, 48 (1978)

3) H.O. House, "Modern Synthetic Reactions " 2 nd. Ed., W.A. Benjawin, Inc., California, 1972, p. 492

4) Y. Ito, T. Konoike, T. Saegusa, J. Am. Chem. Soc., 97, 649 (1975)

5a) C.D. Cook, R.C. Woodworth, J. Am. Chem. Soc., 75, 6242 (1953)

b) C.G. Haynes, A.H. Turner, W.A. Waters, $J$. Chem. Soc., 1956, 2823

6a) C. Chassin, E.A.Schmidt, H.M.R. Hoffmann, J. Am. Chem. Soc., 96, 606 (1974)

b) M.S. Kharasch, H.C. McBay, W.H. Urry, J. Am. Chem. Soc., 70, 1269 (1948)

7) Y.Kobayashi, T. Taguchi, E. Tokuno, Tetrahedron Lett., 1977, 3741

8) S.-i. Inaba, J. Ojima, Tetrahedron Lett., 1977, 2009

9) Y.Ito, M. Nakatsuka, T. Saegusa, J. Org. Chem., in press

10) E.M. Kosower, W. J. Cole, G.-S. Wu, D.E. Cardy, G. Meisters, J. Org. Chem., 28, 630 (1963)

11a) Y. Ito, S. Fujii, T. Saegusa, J. Org. Chem., 41, 2073 (1976)

b) Y. Ito, S. Fujii, M. Nakatsuka, F. Kawamoto, T. Saegusa, "Organic Syntheses" in press

12) P. Amice, L. Blanco, J.M. Conia, Synthesis, 
1976, 196

13) T.L. Macdonald, J. Org. Chem., 43, 3620, 4241 (1978)

14) G.Stork, T.L. Macdonald, J. Am. Chem. Soc., 97, 1264 (1975)

15) Y.Ito, T.Saegusa, J. Org. Chem., 42, 2326 (1977)

16) K. Rühlmann, Synthesis, 1971, 236

17) Y.Ito, T.Sugaya, M. Nakatsuka, T.Saegusa, J. Am. Chem. Soc., 99, 8366 (1977)

18）伊藤，中塚，宮田，三枝，高分子学会予稿集 28 巻 6 号 1150 ページ ( 1979 )

19）安藤，柳，村井，園田，日本化学会第40秋季年会 講演予稿集 III 1042 ページ（1979）
20) G.M. Rubottom, R. Marrero, D.S. Krueger, J. L. Schreiner, Tetrahedron Lett., 1977, 4013

21）Y.Ito, T.Hirao, T.Saegusa，第 25 回 有機金属 化学討論会 (1978)

22) Y.Ito, H. Aoyama, T. Hirao, A. Mochizuki, T. Saegusa, J. Am. Chem. Soc., 101, 494 (1979)

23) Y. Ito, H. Aoyama, T. Saegusa, 第 26 回 有機金 属化学討論会予稿集 187 ページ（1979）

24a) J.E. Bäckvall, Tetrahedron Lett., 1975, 2225

b) J.E. Bäckvall, Tetrahedron Lett., 1977, 467

25) Y. Ito, H. Aoyama, T.Saegusa, unpublished

26) Y.Ito, T.Hirao, T.Saegusa, J. Org. Chem., 43, 1011 (1978)

\section{次号予 定}

「炭素化学」ミニ 特 集

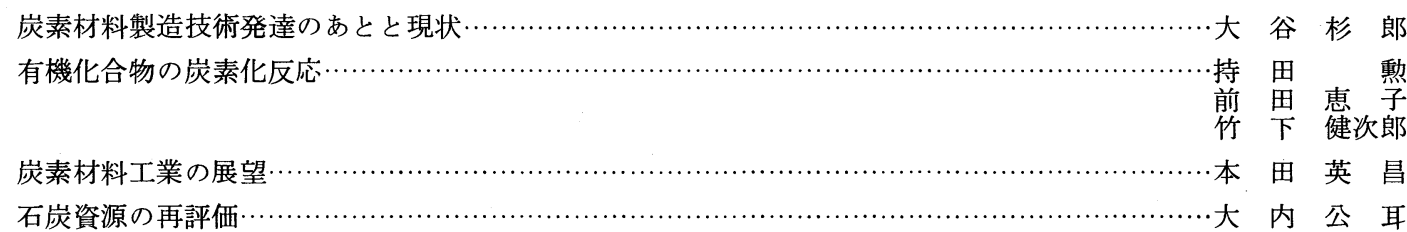

総説

新しい有機合成 野 崎 㟖一郎

グリコシル化合物の化学合成における最近の進歩 津々美 秀 雄

解説

有機化合物の特許分類 後 藤 袁 次

\section{業界情勢}

人工腎臓の動向 尾富一

REVINDEX，新しい合成，他

\section{銀行口座新設のお知らせ}

本協会の近くに第一勧業銀行飯倉支店が開設されたのに伴ない，新口座を設けましたので今後，会費等本会宛の ご送金は下記へお振込み下さいます様にお知らせ旁々お願い申し上げます。

() 取引銀 行

\section{第一勧業銀行 飯倉支店}

普通預金口座Ｎo. 058-1000014 